\title{
Skinning Injury Responses in Sweetpotato
}

\author{
Respons Cedera Kulit pada Ubi Jalar
}

\section{Jollanda Effendy ${ }^{1,2, *}$, Don R. LaBonte ${ }^{3}$, Darda Efendi ${ }^{4}$, Nurul Khumaida ${ }^{4}$, Gustaaf A. Wattimena ${ }^{4}$}

${ }^{1}$ Plant Breeding and Biotechnology Study Program, School of Graduate Studies, IPB University, Dramaga Campus, J1. Raya Dramaga, Bogor 16680, Indonesia

${ }^{2}$ Plant Breeding Study Program, Faculty of Agriculture, Universitas Pattimura. Jl. Ir. M. Putuhena, Kampus Poka, Ambon, 97233, Indonesia

${ }^{3}$ School of Plant, Environmental, and Soil Sciences, Louisiana State University Agricultural Center. 131 J.C. Miller Hall, Baton Rouge, LA 70803, USA

${ }^{4}$ Department of Agronomy and Horticulture, Faculty of Agriculture, IPB University, Dramaga Campus, J1. Raya Dramaga, Bogor 16680, Indonesia

*E-mail Penulis Korespondensi: jeffendy@alumni.sfu.ca

\begin{abstract}
In sweetpotatoes (Ipomoea batatas L. Lamb), the loss of skin from the surface of the storage roots is known as skinning injury. It is responsible for significant postharvest loss resulting from moisture increase and weight reduction, wrinkling, and susceptibility to pathogen attack. Reduced root weight by water loss is associated with a higher rate of rot predominantly occurred in the developing and underdeveloped countries which can count of 8-20\% of postharvest loss. Plants have different adaptation to protect themselves against skinning injury. Lignification, suberization, and increased sugar at the wound site have been shown to be correlated with wound healing. Changing in gene expressions have been associated with skinning injury. Genes associated in the biosynthesis of lignin and suberin, protein fate, cell-wall modification, transcription and protein synthesis, and stress responses and defense have been associated with skinning injury responses in plants. Understanding the skinning injury responses and how to regulate them can be used to produce a more desirable plant resistant to skinning injury. This paper especially reviews and discusses skinning injury responses in sweetpotato, a root crop which product may severely be affected by skinning injury.
\end{abstract}

Keywords: gene expression, Ipomoea batatas, lignification, postharvest loss, wounding

\begin{abstract}
ABSTRAK
Pada ubi jalar (Ipomoea batatas L. Lamb), cedera kulit adalah hilangnya kulit dari permukaan umbi. Cedera kulit ini bertanggung jawab atas kerugian pascapanen yang signifikan akibat peningkatan laju kelembaban dan penurunan berat umbi, pengerutan, dan kerentanan terhadap serangan patogen. Berat umbi yang berkurang karena kehilangan air dikaitkan dengan tingkat pembusukan yang lebih tinggi, terutama terjadi di negara-negara berkembang dan yang kurang berkembang dengan kehilangan hasil panen umbi $8-20 \%$. Tanaman memiliki adaptasi yang berbeda untuk melindungi diri dari cedera kulit. Lignifikasi, suberisasi, dan peningkatan gula di lokasi pelukaan telah terbukti berkorelasi dengan penyembuhan luka. Perubahan ekspresi gen telah dikaitkan dengan cedera kulit. Gen-gen yang terlibat dalam jalur biosintesis lignin dan suberin, protein tujuan akhir, modifikasi dinding sel, transkripsi dan sintesis protein, serta respons stres dan pertahanan telah dikaitkan dengan respons cedera kulit pada tanaman. Memahami respons cedera kulit dan bagimana cara mengaturnya dapat digunakan untuk menghasilkan tanaman yang diinginkan yang tahan terhadap cedera kulit umbi. Paper ini secara khusus mengulas dan membahas respon cedera kulit pada ubi jalar, suatu tanaman umbian yang hasilnya sangat terpengaruh oleh cedera kulit.
\end{abstract}

Kata kunci: ekspresi gen, Ipomoea batatas, lignifikasi, kehilangan pascapanen, pelukaan

\section{INTRODUCTION}

Sweetpotato, with an annual yield of about 91.8 million metric tons and a planted area of 7.77 million hectares, is the seventh important food crop, slightly behind cassava (FAO, 2019). It is a staple food in many nations and produces steady crop yields under a variety of environmental cues. More than $95 \%$ of the world's sweetpotato crop is cultivated in developing nations, where it ranks fifth in terms of fresh weight after rice, wheat, maize, and cassava (Plucknett, 1991). 
The internal flesh of sweetpotato storage roots is mostly constituted of parenchyma cells with starch granules (storage parenchyma) and is covered by the epidermis. The skin, also known as the periderm, is made up of three layers: phellem, phelloderm, and phellogen (Järvinen et al., 2011). The phellogen produces the phelloderm on the inside of the root and the phellem on the outside of the root. The phellem is made up of numerous layers of cells that are free of starch granules and arranged radially toward the phellogen. The phelloderm is more difficult to distinguish from cortical cells since it resembles them, and it is usually differentiated by the radial position of the cells in relation to the phellogen (Kono and Mizoguchi 1982; Villavicencio et al., 2007; Firon et al., 2009).

During sweetpotato growth, the outer peridermal cells get partially lignified and are gradually shed off. The phellogen layer, on the other hand, remains active until harvest, causing the periderm layer thickness to stay unchanged (Artschwager and Starrett, 1931; Villavicencio et al., 2007; Firon et al., 2009). All parenchyma tissues in the tuber maintain the ability to produce new periderm in response to wounding, but it is most prevalent close to the original, native periderm (Artschwager 1927). The phellem cells are characterized in both wound and native periderm by their rectangular form and columnar row structure, and their walls autofluoresce under UV light (Ginzberg, 2008). The autofluorescence is due to presence of aromatic suberin polymers in their cell walls (Bernards and Lewis, 1998). This columnar pattern is a result of their emergence from periclinal division in the phellogen cell layer (Artschwager, 1924).

The loss of the epidermis/skin from the surface of the root, referred to as "skinning," is the major constrain in postharvest handling of sweetpotato roots. Skinning arises when the periderm's superficial layers detach from the underlying tissue, resulting in increased moisture loss, weight loss, shriveling of the root surface, greater vulnerability to pathogen infestations, and an unappealing appearance. 'Beauregard', is the most favored cultivars due to its smooth skin, color and high harvest cultivars in the United States. Unfortunately, following harvest and handling, this cultivar is very susceptible to skin damage (Firon et al., 2009).

Desiccation of the surface cell layers, lignification of the underlying cell layers, and eventually the development of a wound periderm by cell division are all steps in the wound-healing process in sweetpotato storage roots (Artschwager and Starrett, 1931). Improper wound healing is related with a thick dried layer and delayed incomplete lignifications when the humidity is low (van Oirschot et al., 2006). Continuity of the lignified layer is critical for wound healing, apparently to function as a barrier to manage water, mineral nutrients, and vital gas fluxes, as well as to protect against toxic chemical incorporation, water loss, insect infestation, and pathogen attack (van Oirschot et al., 2006; Ranathunge et al., 2011). Van Oirschot et al., (2002) developed a method for measuring wound-healing efficiency using phloroglucinol staining (lignifications score: LS), which has been used to screen sweetpotato cultivars (van Oirschot et al., 2002; 2006).

Because skin loss is caused by the breakdown of peridermal cell walls, Villavicencio et al., (2007) hypothesized that lignin content and polygalacturonase (PG) and pectin methylesterase (PME) activities could be part of the processes or factors that cause raised or lowered skin adhesion in sweetpotato roots. If this is the case, skin adhesion may be related to these factors, allowing them to be used as markers of skinning susceptibility.

\section{SKINNING INJURY AND POSTHARVEST LOSS}

\section{Physical Factors}

Mechanical breakage is the most significant harvest component, with much of it occurring during harvest, transportation, and marketing. In the tropics, harvesting is often done by hand with a range of instruments such as digging sticks, spades, hoes, and knives. Harvesting tools frequently cut, skinned, and bruise sweetpotato storage roots.

\section{Physiological Factors}

Excessive respiration and transpiration in sweetpotato lead to weight loss and changes in internal and external appearance. The evaporative loss of cellular water induced by the vapor pressure differential between the root interior and the outside environment causes transpiration losses. Furthermore, injuring sweetpotato roots led in an increase in both respiration rate and weight loss. Moreover, a condition known as pithiness is defined by the formation of cavities within the tissues as a result of moisture loss. Long-term moisture losses, such as those found in tropical climates, can induce tissue collapse near the root's distal end. This is commonly found in small sized root which could lead to total desiccation (Picha, 1986).

\section{Biological Factors}

Pre-harvest and postharvest infestations by pathogenic microorganisms (mainly fungus, but also bacteria) are major factors of sweetpotato root postharvest loss (Snowdon, 1990). The relative significance of the main diseases varies a lot depending location and environmental situation (Ray and Byju, 2003). 


\section{STRATEGIES ADOPTED BY PLANTS TO AVOID SKINNING INJURY}

Plants have evolved diverse ways to defend themselves against insect and microorganism due to skinning injury. Structurally, plants have a polyester coating composed of cutin and suberin (Kolattukudy, 1980). This coating normally isolates the plant tissues from competing organisms and plants are therefore relatively immune from the presence of these competitors even on their surface. However, if a break or wound occurs in this surface coating, then competing organisms gain entrance into the plant's tissues where they can cause injurious damage to those tissues. Consequently, plants have developed a complex response to wounding that dramatically alters the cellular physiology of plant tissues and results in the production of defenses. These defenses are particularly protection against microorganisms and are effective against small herbivores (Constabel et al., 2000).

A major phase of the wound-response is a generalized activation of plant defenses. Because the majority of microbial infections occur in plants following a wound, plants have developed a range of biochemical defenses to inhibit invading pathogens and small herbivores (Zhou and Thornburg, 1999). The accumulation of phytoalexins after wounding has been a worldwide area for study. Phytoalexin, a small molecular weight defensive compounds, has been shown to have a biological activity against microorganisms or herbivores. For example, phenolic, terpenoid, and alkaloid compounds are a major component of plant secondary metabolism (Zhou and Thornburg, 1999).

Physical barriers (such as wax coats and hardened tissues) and chemical metabolites protect plants from outside harm (Chen et al., 2005). Plants are stimulated to create local and systemic signals in response to mechanical injury and pathogen infestation, which activate signal cascade inside cells (Bergey et al., 1999). Several chemicals were found to be involved in the signaling cascades of defense systems, including hydrogen peroxide, nitric oxide, calcium, protein kinase, jasmonate, salicylic acid, and ethylene (Delaney et al., 1994; Song et al., 1995; O'Donnell et al., 1996; McConn et al., 1997; Zimmermann et al., 1997; Foissner et al., 2000; Orozco-Cárdenas et al., 2001; Gould et al., 2002; Jih et al., 2003; Deng et al., 2013).

\section{SKINNING INJURY INDUCED CHANGES IN GENE EXPRESSION}

Sweetpotato storage roots are underground storage organs with a suberized covering that preserves the interior flesh from dryness and infections. Understanding the molecular mechanisms that lead to the development of periderm is critical for gaining a better understanding of this protective tissue and extending the storage life of storage roots. Moreover, understanding the molecular mechanisms underlying skinning injury, attempts have turned toward the isolation of genes regulated by skinning injury. This also permits insight into their functions and the pathways that lead to their expression. Although several responses of plants to skinning injury, including short-term metabolic and physiological changes are anticipated to be independent of changes in gene expression, the large number are predicted to rely on modification in gene expression.

A common technique that has been used to identify and isolate skinning/wound injury responsive has been the screening of cDNA library constructed from poly(A)+ RNA from skinning injury plants. The encoded products of the genes isolated by this technique are believed to play a role in a number of processes including lignin and suberin biosynthesis pathways, protein fate, cell wall modification, transcription and protein synthesis, and stress response and defense.

\section{Genes Involved in Lignin and Suberin Biosynthesis Pathways}

Suberin is a polymer that has both aliphatic and aromatic domains (Bernards, 2002). The aliphatic suberin is a glycerol-based polyester containing a long and very long chain of $\omega$-hydroxyacids and fatty $\alpha, \omega$-diacids, as well as minute quantities of esterified hydroxycinnamic acids, primarily ferulic acid. Aromatic suberin is a lignin-like polymer that is primarily composed of hydroxycinnamic acids. Longchain acyl-CoA synthethase (LACS), which appears to be involved in the activation of fatty acids prior to elongation (Pollard et al., 2008), and a cytochrome P450 of the CYP94A subfamily, whose putative orthologue in Nicotiana tabacum catalyzes the oxidation of fatty acids to, $\alpha, \omega-$ diacids, are two up-regulated genes for the aliphatic suberin pathway (Le Bouquin et al., 2001). The presence of phenylalanine ammonia lyase (PAL) and caffeic acid 3-O-methyl transferase (COMT) in the aromatic suberin pathway should be emphasized. The enzyme PAL catalyzes the initial step in the phenylpropanoid pathway (Kolattukudy 1981), and its enzymatic activity in the periderm associates with the accumulation of suberin (Bernards et al., 2000; Lulai, 2008). COMT catalyzes the methylation of hydroxylated monomeric lignin precursors in several steps. It is thought to play a key part in the lignin biosynthesis pathway. Wheat cDNA (TaCM) was isolated and shown to be expressed constitutively in the stem, leaf, and root tissues ( $\mathrm{Ma}$ and $\mathrm{Xu}, 2008$ ). TaCM's deduced amino acid sequence has a high similarity with COMT from other plants, especially in the SAM binding motif and the catalytic and substrate specificity regions (Ma and $\mathrm{Xu}, 2008$ ). 


\section{Genes Involved in Protein Fate}

PPIase (parvulin-type peptidyl-prolyl cis-trans isomerase) is thought to be involved in protein folding by catalyzing the cis-trans isomerization of X-Pro peptide bonds. Plant responses to various environmental cues were observed to accumulate PPIase mRNA (Godoy et al., 2000; Reilly et al., 2007; Effendy et al., 2013; 2017). SmTCTP (Soy max translationally controlled tumor protein) gene has a role in protein fate (Gnanasekar et al., 2009). SmTCTP was found to attach to native proteins and conserve them against denaturation due to heat. In bacterial cells, overexpression of TCTP can protect them against heat shock-induced cell death. This result implies that TCTP is a new small molecular weight heat shock protein that functions as a molecular chaperone to guard cellular proteins from heat shock damage (Gnanasekar et al., 2009).

\section{Genes Involved in Cell Wall Modification}

As a result of cell expansion and suberin deposition, changes in cell wall alterations are critical during tuber periderm development. Suberin is accumulated into the main cell wall at the subcellular level. Suberin consists of three components within subdomains of cell walls, depending on the developmental stage of the suberized tissue (Ranathunge et al., 2011). In the potato skin SSH library (Soler et al., 2011), genes involved in cell wall growth and remodeling have been characterized, including pectin-glucuronyltransferase (Iwai et al., 2002; Soler et al., 2011), extensin (Cannon et al., 2008; Soler et al., 2011; Effendy et al., 2013; Neubauer et al., 2013), xyloglucan endotransglucosylase/hydrolase (Fry, 2004; Soler, 2011) and $\beta$-D-glucan exohydrolase (Hrmova and Fincher, 2001).

\section{Genes Involved in Transcription and Protein Synthesis}

Recent studies have revealed differentially expressed genes that involved in transcription and protein synthesis (Zhou and Wu, 2009; Gray et al., 2012). In eukaryotes, transcriptional and posttranscriptional regulation are crucial for gene expression. Transcription factors complete the task of controlling plant stress responses through transregulation (Singh et al., 2002). One of the largest families of plant-specific transcription factors is the NAC protein family (Olsen et al., 2005; Zheng et al., 2009). This family of genes is involved in a variety of biological processes, including biotic and abiotic stress responses, such as drought and salt stress (Zheng et al., 2009). Zinc finger proteins are the most diverse group of transcription factors that regulate gene expression. They have a wide range of structures and functions, including RNA or DNA recognition, RNA packaging, transcriptional activation, protein folding and assembly, and lipid binding (Laity et al., 2001; Zhou et al., 2009a; Zhou and Wu, 2009).

Early in the formation of potato tubers, periderm replaces the epidermis (Reeve et al., 1969). Periderm was shown to have a high level of external and endogenous oxidative stress (Pla et al., 2000). Patatin-like phospholipase, catalase, and ascorbat peroxidase are among the genes implicated in abiotic and biotic stress tolerance found in both native and wound-healing periderm (Chávez et al., 2005; Krits et al., 2007; Barel and Ginzberg, 2008; Ginzberg et al., 2009; Soler et al., 2011). Bernards (2002) revealed that the presence of stress proteins in the periderm is linked to the detoxification of reactive oxygen species (ROS). Furthermore, genes that modulate protein redox status, such as thioredoxin, are induced in the periderm (Bernards, 2002) and storage roots. (Effendy et al., 2013; 2017). The occurrence of genes involved in antioxidant activity and redox homeostasis indicates that redox signaling is important in periderm (Buchanan and Balmer, 2005; Foyer and Noctor, 2005).

Lectins have also been associated as proteins that are involved in defense. Viruses, bacteria, ants, and animals all have lectins, which are carbohydrate-binding proteins (Barondes 1988). Most lectins bind glycoproteins, glycolipids, and polysaccharides (Goldstein and Hayes 1977) and were presumed to assist plants defend themselves against pathogen or insect infestation (Zhu-Salzman et al., 1998; Bandyopadhyay et al., 2001). According to their structures and evolutionary origins, lectins are divided into seven families: legume lectins, type 2 ribosome inactivating proteins, chitin-binding lectins, monocot mannose-binding lectins, cucurbitaceae phloem lectins, jacalin-related lectins (Chang et al., 2012) and others (Damme et al., 1998).

Pathogenesis-related genes, general defense and stress-related genes, genes involved in fatty acid signaling and metabolism, genes for aromatic amino acid metabolism, and genes with unknown functions have all been identified in Arabidopsis. In addition, researchers have uncovered evidence that the octadecanoid signaling system promotes responses to mechanical injury, insect infestation, and UV irradiation. (Conconi et al., 1996; Howe et al., 1996). Wound-inducible genes encode proteins with a variety of functions. Some of them aid in the healing of injured tissue, while others may generate chemicals that suppress insect growth. Wound-inducible proteins were also involved in signaling pathway activation and plant metabolic regulation (León et al., 2001). The sweetpotato ipomoelin (IPO) or sporamin (spor) gene, for example, was identified and its expression was up-regulated by methyl jasmonate and mechanical injury (Imanishi et al., 1997; Chen et al., 2003; Effendy et al., 2013; 2017; 2019). Furthermore, results from feeding silkworms spor protein from Escherichia coli indicated that the spor protein was a protective protein that inhibited silkworm development and survival (Chen et al., 2005). 


\section{CONCLUSIONS}

From various previous studies it has been found that skinning injury clearly causes significant losses in sweetpotato storage root yield. However, plants have different mechanisms to prevent post-harvest losses. Upon harvesting, storage roots undergo post-harvest losses such as physical, physiological, and biological factors. In addition, plants have adopted different strategies to avoid further damage due to skinning injury by activating plant defenses, for example biochemical defenses, physiological barriers and chemical metabolites. Furthermore, changes in gene expression such as transcript accumulation associated with lignin and suberin biosynthesis pathways, cell wall modification, transcript and protein synthesis and stress responses and defense are up-regulated in response to skinning injury.

\section{ACKNOWLEDGMENT}

Funding for this sweetpotato study was provided by Borlaug Fellowship 2011 from the United State Department of Agriculture, Foreign Agricultural Service to JE.

\section{REFERENCES}

Artschwager, E.F. 1924. Studies on the potato tuber. Journal of Agricultural Research 27:809-835.

Artschwager, E. 1927. Wound Epiderm Formation in the Potato as Affected by Temperature and Humidity. Journal of Agricultural Research 43:353.

Artschwager, E.F., and R.C. Starrett. 1931. Suberization and wound-periderm formation in sweet potato and gladiolus as affected by temperature and relative humidity. Journal of Agricultural Research 43:353-364.

Bandyopadhyay, S., A. Roy, and S. Das. 2001. Binding of garlic (Allium sativum) leaf lectin to the gut receptors of homopteran pests is correlated to its insecticidal activity. Plant Science 161(5):1025-1033. DOI: 10.1016/S0168-9452(01)00507-6.

Barel, G., and I. Ginzberg. 2008. Potato skin proteome is enriched with plant defence components. Journal of Experimental Botany 59(12):3347-3357. DOI: 10.1093/jxb/ern184.

Barondes, S.H. 1988. Bifunctional properties of lectins: lectins redefined. Trends in biochemical sciences 13(12):480-482. DOI: 10.1016/0968-0004(88)90235-6.

Bergey, D.R., M. Orozco-Cardenas, D.S. De Moura, and C.A. Ryan. 1999. A wound- and systemin-inducible polygalacturonase in tomato leaves. Proceedings of the National Academy of Sciences of the United States of America 96(4):1756-1760. DOI: 10.1073/pnas.96.4.1756.

Bernards, M.A., and N.G. Lewis. 1998. The macromolecular aromatic domain in suberized tissue: a changing paradigm. Phytochemistry 47(6): 915-933. DOI: 10.1016/s0031-9422(98)80052-6.

Bernards, M.A., L.M. Susag, D.L. Bedgar, A.M. Anterola, and N.G. Lewis. 2000. Induced phenylpropanoid metabolism during suberization and lignification: a comparative analysis. Journal of Plant Physiology 157(6):601-607. DOI: 10.1016/S01761617(00)80002-4.

Bernards, M.A. 2002. Demystifying suberin. Canadian Journal of Botany 80(3): 227-240. DOI: 10.1139/b02-017.

Buchanan, B.B., and Y. Balmer. 2005. Redox regulation: a broadening horizon. Annual Review of Plant Biology 56:187-220. DOI: 10.1146/annurev.arplant.56.032604.144246.

Cannon, M.C., K. Terneus, Q. Hall, L. Tan, Y. Wang, B.L. Wegenhart, L. Chen, D.T.A. Lamport, Y. Chen, and M.J. Kieliszewski. 2008. Self-assembly of the plant cell wall requires an extensin scaffold. Proceedings of the National Academy of Sciences of the United States of America 105(6):2226-2231. DOI: 10.1073/pnas.0711980105.

Chang, W-C., K-L. Liu, F-C. Hsu, S-T. Jeng, and Y-S. Cheng. 2012. Ipomoelin, a jacalin-related lectin with a compact tetrameric association and versatile carbohydrate binding properties regulated by its N terminus. PLoS One 7:e40618. DOI: 10.1371/ journal.pone.0040618.

Chávez, A.L., T. Sánchez, G. Jaramillo, J. Bedoya, J. Echeverry, E. Bolaños, H. Ceballos, and C.A. Iglesias. 2005. Variation of quality traits in cassava roots evaluated in landraces and improved clones. Euphytica 143(1-2):125-133. DOI: 10.1007/ s10681-005-3057-2.

Chen, Y.C., H.S. Chang, H.M. Lai, and S.T. Jeng. 2005. Characterization of the wound-inducible protein ipomoelin from sweet potato. Plant, Cell and Environment 28(2):251-259. DOI: 10.1111/j.1365-3040.2005.01271.x.

Chen, Y.C., B.W. Tseng, Y.L. Huang, Y.C. Liu, and S.T. Jeng. 2003. Expression of the ipomoelin gene from sweet potato is regulated by dephosphorylated proteins, calcium ion and ethylene. Plant, Cell and Environment 26(8):1373-1383. DOI: 10.1046/j.0016-8025.2003.01062.x.

Conconi, A., M.J. Smerdon, G.A. Howe, and C.A. Ryan. 1996. The octadecanoid signalling pathway in plants mediates a response to ultraviolet radiation. Nature 383(6603):826-829. DOI: 10.1038/383826a0.

Constabel, C.P., L. Yip, J.J. Patton, and M.E. Christopher. 2000. Polyphenol oxidase from hybrid poplar. Cloning and expression in response to wounding and herbivory. Plant Physiology 124(1):285-295. DOI: 10.1104/pp.124.1.285. 
Damme, E.J.V., W.J. Peumans, A. Barre, and P. Rougé. 1998. Plant lectins: a composite of several distinct families of structurally and evolutionary related proteins with diverse biological roles. Critical Reviews in Plant Sciences 17(6):575-692. DOI: 10.1080/07352689891304276.

Delaney, T.P., S. Uknes, B. Vernooij, L. Friedrich, K. Weymann, D. Negrotto, T. Gaffney, M. Gut-Rella, H. Kessmann, and E. Ward. 1994. A central role of salicylic acid in plant disease resistance. Science 266(5188):1247-1250. DOI: 10.1126/ science.266.5188.1247.

Deng, W.W., M. Zhang, J.Q. Wu, Z.Z. Jiang, L. Tang, Y.Y. Li, C.L. Wei, C.J. Jiang, and X.C. Wan. 2013. Molecular cloning, functional analysis of three cinnamyl alcohol dehydrogenase (CAD) genes in the leaves of tea plant, Camellia sinensis. Journal of Plant Physiology 170(3):272-282. DOI: 10.1016/j.jplph.2012.10.010.

Effendy, J., D.R. LaBonte, and N. Baisakh. 2013. Identification and expression of skinning injury-responsive genes in sweetpotato. Journal of the American Society for Horticultural Science 138(3):210-216. DOI: 10.21273/JASHS.138.3.210.

Effendy, J., D. Efendi, N. Khumaida, and G.A. Wattimena. 2017. Functional classification of skinning injury responsive genes in storage roots of sweetpotato. Jurnal Agronomi Indonesia 45(1):36-42. DOI: 10.24831/jai.v45i1.11667.

Effendy, J., D.R. LaBonte, and D. Efendi. 2019. Isolation and characterization of cDNA clones encoding a novel subfamily sporamin B in sweet potato. Biodiversitas 20(10):3033-3041. DOI: 10.13057/biodiv/d201036.

Firon, N., D. LaBonte, A. Villordon, C. McGregor, Y. Kfir, and E. Pressman. 2009. Botany and physiology: storage root formation and development. In G. Loebenstein and G. Thottappilly (eds.) The Sweetpotato. pp. 13-26. Springer. Dordrecht. 522 p. ISBN 978-1-4020-9475-0. DOI: 10.1007/978-1-4020-9475-0_3.

Foissner, I., D. Wendehenne, C. Langebartels, and J. Durner. 2000. In vivo imaging of an elicitor-induced nitric oxide burst in tobacco. Plant Journal 23(6):817-824. DOI: 10.1046/j.1365-313x.2000.00835.x.

Food and Agriculture Organization of the United Nations. 2016. FAOSTAT Database. Rome, http://www.fao.org/faostat/ en/\#data/QC. Accessed: May 23, 2021.

Foyer, C.H., and G. Noctor. 2005. Redox homeostasis and antioxidant signaling: a metabolic interface between stress perception and physiological responses. Plant Cell 17(7):1866-1875. DOI: 10.1105/tpc.105.033589.

Fry, S.C., 2004. Primary cell wall metabolism: tracking the careers of wall polymers in living plant cells. New Phytologist 161(3):641-675. DOI: 10.1111/j.1469-8137.2004.00980.x.

Ginzberg, I., G. Barel, R. Ophir, E. Tzin, Z. Tanami, T. Muddarangappa, W. De Jong, and E. Fogelman. 2009. Transcriptomic profiling of heat-stress response in potato periderm. Journal of Experimental Botany 60(15):4411-4421. DOI: 10.1093/jxb/ $\operatorname{erp} 281$.

Ginzberg, I. 2008. Wound-periderm formation. In A. Schaller (ed.) Induced plant resistance to Herbivory. pp. 131-146. Springer. Dordrecht. 462 p. ISBN 978-1-4020-8182-8. DOI: 10.1007/978-1-4020-8182-8_6.

Gnanasekar, M., G. Dakshinamoorthy, and K. Ramaswamy. 2009. Translationally controlled tumor protein is a novel heat shock protein with chaperone-like activity. Biochemical and Biophysical Research Communications 386(2):333-337. DOI: 10.1016/j.bbrc.2009.06.028.

Godoy, A.V., A.S. Lazzaro, C.A. Casalongué, and B. San Segundo. 2000. Expression of a Solanum tuberosum cyclophilin gene is regulated by fungal infection and abiotic stress conditions. Plant Science 152(2):123-134. DOI: 10.1016/S0168-9452(99) 00211-3.

Goldstein, I.J., and C.E. Hayes. 1978. The lectins: carbohydrate-binding proteins of plants and animals. Advances in carbohydrate chemistry and biochemistry 35:127-340. DOI: 10.1016/s0065-2318(08)60220-6.

Gould, K., J. McKelvie, and K. Markham. 2002. Do anthocyanins function as antioxidants in leaves? Imaging of $\mathrm{H}_{2} \mathrm{O}_{2}$ in red and green leaves after mechanical injury. Plant, Cell and Environment 25(10):1261-1269. DOI: 10.1046/j.1365-3040.2002. 00905.x.

Gray, J., D. Caparros-Ruiz, and E. Grotewold. 2012. Grass phenylpropanoids: regulate before using! Plant Science 184:112-120. DOI: 10.1016/j.plantsci.2011.12.008.

Howe, G.A., J. Lightner, and C. Ryan. 1996. An octadecanoid pathway mutant (JL5) of tomato is compromised in signaling for defense against insect attack. Plant Cell 8(11):2067-2077. DOI: 10.1105/tpc.8.11.2067.

Hrmova, M., and G.B. Fincher. 2001. Structure-function relationships of $\beta$-D-glucan endo-and exohydrolases from higher plants. Plant Molecular Biology 47(1-2): 73-91. DOI: 10.1023/A:1010619128894.

Imanishi, S., K. Kito-Nakamura, K. Matsuoka, A. Morikami, and K. Nakamura. 1997. A major jasmonate-inducible protein of sweet potato, ipomoelin, is an ABA-independent wound-inducible protein. Plant and Cell Physiology 38(6): 643-652. DOI: 10.1093/oxfordjournals.pcp.a029216.

Iwai, H., N. Masaoka, T. Ishii, and S. Satoh. 2002. A pectin glucuronyltransferase gene is essential for intercellular attachment in the plant meristem. Proceedings of the National Academy of Sciences of the United States of America 99(25):16319-16324. DOI: $10.1073 /$ pnas.252530499.

Järvinen, R., H. Rauhala, U. Holopainen, and H. Kallio. 2011. Differences in suberin content and composition between two varieties of potatoes (Solanum tuberosum) and effect of post-harvest storage to the composition. LWT-Food Science and Technology 44(6):1355-1361. DOI: 10.1016/j.lwt.2011.02.005.

Jih, P.J., Y.C. Chen, and S.T. Jeng. 2003. Involvement of hydrogen peroxide and nitric oxide in expression of the ipomoelin gene from sweet potato. Plant Physiology 132(1):381-389. DOI: 10.1104/pp.102.015701.

Kolattukudy, P. 1980. Biopolyester membranes of plants: cutin and suberin. Science 208(4447):990-1000 . DOI: 10.1126/science. 208.4447.990. 
Kolattukudy, P. 1981. Structure, biosynthesis, and biodegradation of cutin and suberin. Annual Review of Plant Physiology 32(1):539-567. DOI: 10.1146/annurev.pp.32.060181.002543.

Kono, Y., and .T Mizoguchi. 1982. The origin of root periderm in the sweet potato plant, Ipomoea batatas Lam. Japanese Journal of Crop Science 51(4):535-541. ISSN: 0011-1848.

Krits, P., E. Fogelman, and .I Ginzberg. 2007. Potato steroidal glycoalkaloid levels and the expression of key isoprenoid metabolic genes. Planta 227(1):143-150. DOI: 10.1007/s00425-007-0602-3.

Laity, J.H., B.M. Lee, and P.E. Wright. 2001. Zinc finger proteins: new insights into structural and functional diversity. Current Opinion in Structural Biology 11(1):39-46. DOI: 10.1016/s0959-440x(00)00167-6.

Le Bouquin, R., M. Skrabs, R. Kahn, I. Benveniste, J.P. Salaün, L. Schreiber, F. Durst, and F. Pinot. 2001. CYP94A5, a new cytochrome P450 from Nicotiana tabacum is able to catalyze the oxidation of fatty acids to the $\omega$-alcohol and to the corresponding diacid. European Journal of Biochemistry 268(10): 3083-3090. DOI: 10.1046/j.1432-1327.2001.02207.x.

León, J., E. Rojo, and J.J. Sánchez-Serrano. 2001. Wound signalling in plants. Journal of Experimental Botany 52:1-9. DOI: 10.1093/jexbot/52.354.1.

Lulai, E.C. 2008. Skin-set and Wound-healing/Suberization. Potato Research 50(3-4):387-390. DOI: 10.1007/s11540-008-9067-4.

Ma, Q.H., and Y. Xu. 2008. Characterization of a caffeic acid 3-O-methyltransferase from wheat and its function in lignin biosynthesis. Biochimie 90(3): 515-524. DOI: 10.1016/j.biochi.2007.09.016.

McConn, M., R.A. Creelman, E. Bell, and J.E. Mullet. 1997. Jasmonate is essential for insect defense in Arabidopsis. Proceedings of the National Academy of Sciences of the United States of America 94(10):5473-5477. DOI: 10.1073/pnas.94.10.5473.

Neubauer, J.D., E.C. Lulai, A.L. Thompson, J.C. Suttle, M.D. Bolton, and L.G. Campbell. 2013. Molecular and cytological aspects of native periderm maturation in potato tubers. Journal of Plant Physiology 170(4):413-423. DOI: 10.1016/j.jplph.2012. 10.008 .

O'Donnell, P., C. Calvert, R. Atzorn, C. Wasternack, H. Leyser, and D. Bowles. 1996. Ethylene as a signal mediating the wound response of tomato plants. Science 274(5294):1914-1917. DOI: 10.1126/science.274.5294.1914.

Olsen, A.N., H.A. Ernst, L.L. Leggio, and K. Skriver. 2005. NAC transcription factors: structurally distinct, functionally diverse. Trends in Plant Science 10(2): 79-87. DOI: 10.1016/j.tplants.2004.12.010.

Orozco-Cárdenas, M.L., J. Narváez-Vásquez, and C.A. Ryan. 2001. Hydrogen peroxide acts as a second messenger for the induction of defense genes in tomato plants in response to wounding, systemin, and methyl jasmonate. Plant Cell 13(1): 179-191. DOI: $10.1105 /$ tpc.13.1.179.

Picha, D.H. 1986. Influence of storage duration and temperature on sweet potato sugar content and chip color. Journal of Food Science 51(1): 239-240. DOI: 10.1111/j.1365-2621.1986.tb10883.x.

Pla, M., A. Jofré, M. Martell, M. Molinas, and J. Gómez. 2000. Large accumulation of mRNA and DNA point modifications in a plant senescent tissue. FEBS Lett. 472(1): 14-16. DOI: 10.1016/S0014-5793(00)01424-1.

Plucknett, D. 1991. Foreword. In R.K. Janson \& K.V. Raman (eds.) Sweet potato pest management: a global perspective. pp. xi-xii. Westview Press. San Franscisco, CA. 458 p. DOI: 10.1201/9780429308109, ISBN: 9780429308109.

Pollard, M., F. Beisson, Y. Li, and J.B. Ohlrogge. 2008. Building lipid barriers: biosynthesis of cutin and suberin. Trends in Plant Science 13(5): 236-246. DOI: 10.1016/j.tplants.2008.03.003.

Ranathunge, K .J., Lin, E. Steudle, and L. Schreiber. 2011. Stagnant deoxygenated growth enhances root suberization and lignifications, but differentially affects water and $\mathrm{NaCl}$ permeabilities in rice (Oryza sativa L.) roots. Plant, Cell and Environment 34(8): 1223-1240. DOI: 10.1111/j.1365-3040.2011.02318.x.

Ray, R., and G. Byju. 2003. Root surface culturable microflora associated with post harvest spoilage of sweet potato (Ipomoea batatas L.). Advances in Horticultural Science 17(3): 176-180.

Reeve, R.M., E. Hautala, and M.L. Weaver. 1969. Anatomy and compositional variation within potatoes II. Phenolics, enzymes and other minor components. American Potato Journal 46: 374-386. DOI: 10.1007/BF02869558.

Reilly, K., D. Bernal, D.F. Cortes, R. Gomez-Vasquez, J. Tohme, and J.R. Beeching. 2007. Towards identifying the full set of genes expressed during cassava post-harvest physiological deterioration. Plant Molecular Biology 64(1-2): 187-203. DOI: 10.1007/s11103-007-9144-0.

Singh, K.B., R.C. Foley, and L. Oñate-Sánchez. 2002. Transcription factors in plant defense and stress responses. Current Opinion in Plant Biology 5(5): 430-436. DOI: 10.1016/s1369-5266(02)00289-3.

Snowdon, A.L. 1990. A color Atlas of post-harvest diseases and disorders of fruits and vegetables. In A.L. Snowdon (ed.) General Introductions and fruits. pp. 78-79. Wolfe Publishing, London. 302 p. ISBN: 0723409315.

Soler, M., O. Serra, S. Fluch, M. Molinas, and M. Figueras. 2011. A potato skin SSH library yields new candidate genes for suberin biosynthesis and periderm formation. Planta 233(5): 933-945. DOI: 10.1007/s00425-011-1350-y.

Song, W-Y., G-L. Wang, L-L. Chen, H-S. Kim, L-Y. Pi, T. Holsten, J. Gardner, B. Wang, W-X. Zhai, and L-H. Zhu. 1995. A receptor kinase-like protein encoded by the rice disease resistance gene, Xa21. Science 270(5243): 1804-1806. DOI: 10.1126/science.270.5243.1804.

van Oirschot, Q., D. Rees, C. Lucas, D. Maina, T. Mcharo, and J. Bohac. 2002. Sweetpotato: germplasm evaluation for wound healing efficiency. 22 pp. Paper presented at the International Symposium, Sweetpotato: food for health and future, Lima, Peru. 26-29 November 2001.[abstract].

van Oirschot, Q.E.A., D. Rees, J. Aked, and A. Kihurani. 2006. Sweetpotato cultivars differ in efficiency of wound healing. Postharvest Biology and Technology 42 (1): 65-74. DOI: 10.1016/j.postharvbio.2006.05.013. 
Villavicencio, L.E., S.M. Blankenship, G.C. Yencho, Thomas J.F., and C.D. Raper. 2007. Temperature effect on skin adhesion, cell wall enzyme activity, lignin content, anthocyanins, growth parameters, and periderm histochemistry of sweetpotato. Journal of the American Society for Horticultural Science 132(5): 729-738. DOI: 10.21273/JASHS.132.5.729.

Zheng, X., B. Chen, G. Lu and B. Han. 2009. Overexpression of a NAC transcription factor enhances rice drought and salt tolerance. Biochemical and Biophysical Research Communications 379(4): 985-989. DOI: 10.1016/j.bbrc.2008.12.163.

Zhou, J., F. Li, J.L. Wang, Y. Ma, K. Chong, and Y.Y. Xu. 2009. Basic helix-loop-helix transcription factor from wild rice (OrbHLH2) improves tolerance to salt- and osmotic stress in Arabidopsis. Journal of Plant Physiology 166(12): 1296-1306. DOI: 10.1016/j.jplph.2009.02.007.

Zhou, L., and R. Thornburg. 1999. Wound-inducible genes in plants. In P.H.S. Reynolds (ed.) Inducible gene expression in plants. pp. 127-168. CABI Publishing._New York, NY. 247 p. ISBN: 9780851992594.

Zhou, X. and F. Wu. 2009. Differentially expressed transcripts from cucumber (Cucumis sativus L.) root upon inoculation with Fusarium oxysporum f. sp. cucumerinum Owen. Physiological and Molecular Plant Pathology 74(2): 142-150. DOI: 10.1016/J.PMPP.2009.10.005.

Zhu-Salzman, K., R.E. Shade, H. Koiwa, R.A. Salzman, M. Narasimhan, R.A. Bressan, P.M. Hasegawa, and L.L. Murdock. 1998. Carbohydrate binding and resistance to proteolysis control insecticidal activity of Griffonia simplicifolia lectin II. Proceedings of the National Academy of Sciences of the United States of America 95(25): 15123-15128. DOI: 10.1073/pnas. 95.25.15123.

Zimmermann, S, T. Nürnberger, J-M. Frachisse, W. Wirtz, J. Guern, R. Hedrich, and D. Scheel. 1997. Receptor-mediated activation of a plant $\mathrm{Ca}^{2+}$-permeable ion channel involved in pathogen defense. Proceedings of the National Academy of Sciences of the United States of America 94(6): 2751-2755. DOI: 10.1073/pnas.94.6.2751. 